УДК 811.1:81’42

Людмила ДЖИГУН,

кандидат педагогічних наук, доцент, Хмельницький національний університет

\title{
ДИСКУРС АВТОБІОГРАФІЗМУ В СПОГАДАХ ПИСЬМЕННИКІВ УКРАЇНСЬКОЇ ЕМІГРАЦІЇ
}

У статті доведено, що авторська суб'єктивність організує твір, породжує його художню цілісність і має різні форми вияву. Спрямованість мислення Григорія Костюка на той чи інший предмет, дію, явище виформовується в думку, яка зафіксована на папері і $є$ наслідком інтенційної комунікації у формі монологу, я-висловлювань. У такий спосіб особисте ставлення до предмета зображення, втілене в мовній структурі твору, є виявом образу автора, його певної світоглядної позиції.

Ключові слова: поетика, мемуаристика, автобіографія, контекст, образ автора.

Постановка проблеми. У галузі автобіографіки працювали В. Минко, Ю. Смолич, О. Довженко, В. Сосюра, М. Рильський та ін., твори яких не суперечили марксистсько-ленінській методології, а були написані в дусі соцреалізму. Водночас значного успіху досягла еміграційна мемуарна література, авторами якої були Д. Гуменна, М.Цуканова, Д. Нитченко, І. КосачБорисова, Анатоль Галан (Калиновський), Ю. Шевельов, Г. Костюк. Теоретичне обгрунтування автодокументального жанру, за визначенням французького літературознавця Филипа Лежена, як документа людини і про людину [7], точніше, документа антропологічного спрямування, стало в центрі уваги сучасних дослідників, з-поміж яких Т. Черкашина, О. Галич, О.Рарицький, С. Срьоменко, Г. Мазоха, Т. Швець, А. Цяпа та ін. Однак поетики автобіографізму спогадів Г. Костюка досі ніхто не розглядав, хоч "его-тексти" щедро наповнюють структуру його нефікційної прози.

Mета статmi - автобіографічний наратив у мемуарній прозі Г. Костюка крізь прочитання філософських концепцій, спогадів його побратимів по перу.

Виклад основного матеріалу. Мемуарна література $є$ досить цікавим й унікальним зразком словесної творчості. Н. Арутюнова вважає, що дискурс - це мовлення, занурене в життя [1, с. 136-137]. Все більше вітчизняні та іноземні дослідники вивчають різновекторні аспекти літератури факту. Тож у 
дослідженні спробуємо розглянути авторську гру 3 формою та змістом автобіографіки спогадової літератури. Намагатимемося виявити найбільш характерні форми взаємодії автора та читача на всіх рівнях тексту, також розглянути паратекстні особливості біографічної прози. Адже літературний персонаж виражає почуття, сум чи радість, захоплення, докір тощо, виявляє відповідний тон в усній промові, а в письмовій формі це передано пунктуацією.

Прикметно, коли совєтські мемуаристи В. Минко, В. Сосюра, Ю. Смолич, Т. Масенко, Ю. Кобилецький, І. Дузь, С. Голованівський аспекти власного життя намагалися оминати в автобіографічній творчості, а в авангарді йшла суспільна думка, громадські справи людини - будівника безкласового суспільства під керівництвом керівної сили, - автори більше дбали про зміст, ніж про форму. Натомість діаспорні письменники відкидали «плакатного діяча», спроектовували увагу, втілення художнього задуму на живу діяльну людину, просопографічні тенденції. За допомогою спогадів автори вдавалися до самопорятунку. Російський філолог українського походження К. Мочульський спогадову літературу так характеризував: «Пережити відчайдушно-трагічну, екзистенціальну долю людини в чистоті, без маскування його налагодженим комфортним побутом, соціальним успіхом, давала ідеально-безнадійна, маргінальна обстановка еміграції. I це нове переживання, донесення його до читача, для молодого покоління було головною місією письменника. Трагічна екзистенціальна проблематика особистості в іiі відносинах зі смертю, часом, природою, Богом і боговідступництвом, з абсурдом тощо - це було дійсно щось нове, нова нота, яка сприймається не вельми добре» [10, с. 137].

Очевидно, К.Мочульському йдеться про занепад літературного вимислу, кризу творчої уяви, водночас у його тезі лунає особливе традиційно-духовне завдання, яке притаманне українській літературі на відміну від модерної європейської. Автор намагається переконати реципієнта збагнути істину про людину та їі буття в соціумі через духовний простір, проникнути в божественну суть речей, що оточують людину, але проникнути 3 методологією нової 
ISSN 2308-1902 Актуальні проблеми української літератури і фольклору. 2017. № 25.

європейської філософії. I таке подається як наукова істина. Іншими словами, літературна еміграція поставила перед собою традиційне завдання в нетрадиційних умовах вхопити, зрозуміти хаотичну дійсність XX століття, яка щоразу змінюється, не дозволяючи людині налагодити стабільний, комфортний побут у світі, удосконалити, як належить, цей світ. Тому К.Мочульський таку істину потлумачує «новою нотою, яка сприймається не вельми добре» в екзистенційному вимірі, бо, на його переконання, є боговідступництвом.

При такому науково-методологічному підході до творчого процесу уява в письменницькому інструментарії редукується (послаблюється) тому, що його функції переходять до зовнішнього світу. Ірраціональні роздуми К. Мочульського скеровують читача на відірваність від реалій життя, тоді, як мемуари $є$ наслідком мислення про цей світ. Мемуарист знає, які факти з його життя цікаві для реципієнта, а які слід відкинути, оминути. Певна річ, єдиною константою в літературних мемуарах насправді $є$ сама людина. Тому автор спогадової літератури ніяк не може вдаватися до вимислу, адже найперша його невситима потреба є в самопізнанні й побудові власного «Я» та «Іншого»людини XX століття. Водночас не слід і відкидати домисел (домислювати друзів, ворогів, які зустрічалися на життєвій дорозі), тим паче робота уяви $\epsilon$ психологічною підставою для цього. Відтак ми виходимо на простір суб'єктивності. Скажімо, коли Ю.Шевельов написав спогади «Я - мене - мені... (i довкруги)», то з приводу спогадів з'явилися критичні матеріали М.Наєнка «Що приховують мемуари Юрія Шевельова (Шереха)?» [11, с. 11], американського славіста Г. Г. Ланта «3 приводу спогадів Шевельова» [3]. Критики звертають увагу на суб'єктивний характер мемуарів, в яких оприявнено особистість автора та його світогляд, адже «суб'єктивність дає змогу побачити концепцію певного історичного періоду в подіях і людях очами письменника» [2, с. 195].

3 нашого погляду, історія життя однієї людини висвітлює цілий спектр суспільних проблем, штрихових чи повнометражних образів людей, з якими 
автор тісно співпрацював, спілкувався, безпосередньо чи опосередковано контактував. Мова - найпотужніший засіб передачі інформації. Саме через мову людина висловлює важливі почуття, емоції, основи ораторського мистецтва. Тому публічну мову автора розглядаємо як своєрідний твір мистецтва. Якщо йти за Джоном Серлі, який подає низку мовних класифікацій, що всорбовують у себе закладені в них комунікативні наміри (інтенції) мовця, то у двотомних спогадах Костюка є усі типи іллокутивних (немовних) актів, функцій мовлення: констативи, комісиви (наратор бере на себе ту чи іншу обіцянку), директиви (спонукання адресата), експресиви (подяка, вибачення, поздоровлення, співчуття), декларативи (оголошення про громадське чи офіційне призначення, присвоєння імені, псевдоніма, початок чи закінчення будь-якої церемонії) [12]. Листи, спогади Г. Костюка, його літературно-критичні праці переконують, що він був прекрасним оратором. Галина Кошай пригадує промову (усну оповідь), яку виголосив науковець-філолог 11 грудня 1998 року (маючи за плечима 96 років життя), нею вразив усіх присутніх... «Його пам'яті можна було позаздрити. Він говорив чітко, виразно, логічно і гарно. Коли Григорій Олександрович говорив, то присутні ніби переглядали кадри фільму» [6, с. 50]. Це ще один промовистий штрих до мовного портрета автора. Отже, мовна особистість пізнається через ії текстовий (дискурсний) прояв, бо саме за текстовим наповннням прозописьма стоїть особистість, яка майстерно володіє системою української мови.

Автор спогадів «Зустрічі і прощання» був прекрасним стилістом, майстром художнього стилю. Наратор не ховається за Іншого, його Я водночас демонструє антетичність до світу іншого, дореволюційного. Про мітинг у Кам'янці-Подільському 30 червня 1917 р. згадував: «Щось зачитували, щось схвалювали (декларативи. - Л.Д.). Я нічого не пам'ятаю. Закінчилась демонстрація могутнім співом «Ще не вмерла» (що я почув уперше) i «Заповітом»... Тяжка літня праця не загальмувала ні моєї пристрасти до книжки, ні моїх бесід про світобудову, ні моєї участи у співочому та 
ISSN 2308-1902 Актуальні проблеми української літератури і фольклору. 2017. № 25.

літературному гуртку в «Просвіті». Це вже була моя стихія. Я нею жив» $[4, \mathrm{c}$. 31]. Оповідач розпрозорює у тексті формування світогляду на національній основі, від якого ніколи не відмовлявся i з яким ішов на всіх шляхах $\mathrm{i}$ перехрестях, що стрічалися на його віку. Це ше один яскравий приклад до біографії письменника.

Мовна комунікація, вкрапленя діалогів, полілогів, монологів у структурі мемуарів $є$ посутньою інформаційно-знаковою системою, в якій взаємодіють індивідуальні, національні та інтернаціональні мовні компоненти. Функціонування цієї системи має історичну i соціально-культурну зумовленість. У центрі інформаційно-знакової системи - наратор, творець мовлення як цілеспрямованої дії. У структурі тексту оповідач увиразнює власне Я, ефективно використовує лінгвістичні, соціолінгвістичні, прагматичні аспекти комунікації, наочно розкриває правила комунікативної поведінки в різних ситуаціях. Наприклад, автор демонструє повчання малого сина Теодора, який до Уласа Самчука звертався на «ти». Коли Г. Костюк намагався довести дитині, що дядя Улас - твій хресний батько, тому годиться його поважати, то хлопчик за підтримкою звернувся до мами: «Мамо, ми ж з дядьком Уласом товариші. Ти ж знаєш». Улас Самчук глибоко розумів дитячий світ. Автор мемуарів відверто зізнається: «Я батько, але я ніколи не міг бавитися з сином так природно й самозабутньо, як умів це Улас Олексійович» [5, с. 197-198].

Проілюстрований матеріал переконливо підтверджує, що для Г. Костюка найважливішим із засобів відображення власного життя й оточення була мова. У ній постає сила образності, краса, виразність. Образна система має у своїй основі унормовану українську літературну мову із незначними епізодичними вкрапленнями розмовної лексики. Важливу функцію в нефікційній прозі беруть на себе зображувальні засоби, що склалися в мовленні українців минулого століття. Спогади, літературні праці написано рукою зрілого майстра, фахового філолога, який розуміє значення кожного слова, а отже, текст атрибутує високу зображувальну культуру. 
Проаналізувавши «Зустрічі і прощання», спостерегли, що Г. Костюку притаманні різноманітні виражальні властивості: художні засоби, риторичні прийоми, інтонація, інверсія, еліпсис, наголос, що відповідно впливають на того, хто сприймає текст. Особливої уваги заслуговує просодична характеристика мовлення, автор майстерно будує речення, вдаючись до інтонаційно-логічних, фразових акцентів, пауз, недомовленості. Саме просодичні елементи мовлення (акцентація слів та їх частин, співвідношення відрізків мовлення, паузи), їх функціонування в документальній прозі сприяють ліризації тексту, кращому його сприйняттю реципієнтом. Мемуарист використовує психологічні паузи, які збагачують зміст нефікційної прози, підсилюють напруження, очікування читача, викликають певні асоціації, вказують на подальшу дію, пояснення або певну оцінку оприявненого факту.

У двадцятому столітті виняткова роль автобіографістики «виявляється у збереженні історичної пам'яті, у самопізнанні людини та нації» [8, с. 11]. Якщо брати за основу «Зустрічі і прощання», то за цією фундаментальною працею можна писати сценарій, створювати кінофільм, захищати дисертацію з історії української літератури XX століття. Через долю авторського Я прочитується множинність Іншого: оточення, довкілля, суспільно-політичні зрушення, культурні ініціативи, сотні людських характерів, філософія менталітету вкраїнської спільноти, творення вітчизняної літератури в діаспорі, функціонування літературних об'єднань МУР і «Слово», збереження й пропаганда літературної спадщини репресованих і замовчуваних письменників: В. Винниченка, М. Хвильового П. Филиповича, М. Куліша, М. Драй-Хмари. А за цим - наполеглива редакторська й літературна праця, сотні недоспаних ночей. Через біографію Г. Костюка проходить історія України, народу і нації упродовж трагедійного XX століття. Автобіографічний дискурс у такому ключі втрачає часовий вимір (історія життя), набуває ширшого просторового ландшафту, тобто влаштованості Себе в розгойданому світі й буття доокруж себе. 
Автобіографічний текст оприявнює не лише фактичні дані власного життєвого досвіду, а й довкола внутрішного сповідального Я об'єднує документальні й художні риси. Як стверджує англійський науковець Давид Герман, автобіографія - це «не просто хронологічне викладення фактів, а літературне оформлення деталей і подій, які набувають статусу фактів у процесі створення певною людиною образу самої себе» [16]. Малюючи словесні портрети С. Божка чи Т. Масенка, I. Багряного чи Галини Журби, Тодося Осьмачки чи Докії Гуменної, автор спогадів у порівнянні образу-«Іншого» намагається уникнути, втекти від суб'єктивності, розкрити глибше власну присутність у процесі художнього відтворення дійсності, особисту участь у літературному житті. Г. Костюк під час особистого життєконструювання перебував у світі стабільних і нестабільних феноменів, тож у точці «перелому» намагався віднайти себе. Відчувається, коли мемуарист заторкує час суттєвих змін, боротьби за власну автентичність, він оприявнює боротьбу внутрішнього Я за стійкість до випробувань долі, виформовуючи позитивні сугестивні комплекси, почуття відповідальності за своє життя, готовність прожити відведений природою час у продуктивній самореалізації.

Щодо тих моментів, які автор оминув, які залишилися поза його свідомістю, а деякі місця в тексті позначені суб'єктивністю, то тут знову ж таки зішлемося на Д. Германа, який зауважує, що «автобіографії - це не відкриті фактичні літописи, а хитрі маніпуляції деталями та подіями, що набувають статусу фактів при побудові конкретної особи як самосвідомості. Водночас конструктивістська інтерпретація автобіографічного дискурсу сама по собі не зобов'язує нас читати автобіографії так, як ми читаємо фікції» [16]. Тобто, дієсловом «не зобов'язує» автор натякає, що слід звертати увагу на художню вигадку, стилістичні фігури, алюзії, які читач віднаходить у нефікційній прозі. Але ж мова йде не про художній текст, де переважає умовність. У документалістиці фікції загалом не повинно бути. Добре розумів такий феномен мемуарист, який у передмові зазначив: «Мій закон - як і досі було, та і тепер - 
писати саму правду. Грунтуються мої нотатки на записках, які я, на щастя, вів тоді, і на моїй пам'яті» [5, с. 5].

Звернувшись до філологічного аналізу нефікційної прози, помітним є той факт, що зміни в поетиці автобіографізму зумовлені глибиною зміни самої суб’єктної структури літературного героя, коли «рольовий» тренд авторського «Я» плавно спроектовується на «Я»-інший. Англійський літературознавець Б. Бергонці, заторкуючи емоційний текст, висловлює квінтесенцію, що піднесена мова, тональність відсторонена від презентації предмета, нагадує йому роботи європейських художників-експресіоністів, позаяк емоційна мова «енергійна, щільна, навіть шорстка за своєю словесною структурою, емоційна, і - дещо відсторонена в презентації предмета» [15, с. 418].

Автобіографізм оповідача іноді приховується за низкою займенників, іменників, і тоді граматично наратора-суб'єкта статус дещо видозмінений через прочитання «ми», «я», «мені», «люди», «хтось», «він», «Ти», «всі», «мої мрії», «моє дитинство», «мої старання». Означений статус радикально увиразнює суб'єкта, який перебуває в собі, на чому наголошує С.Бройтман, автор історичної поетики [13, с. 344]. За іменниково-займенниковою семантикою, словосполуками упізнаваною є поетика автобіографізму. Показовим при цьому є заголовок спогадів Ю. Шевельова «Я - мене - мені... (і довкруги)», в яких автор, заторкуючи образ матері, виходить на простір Я-ідентичність: «моє українство від предків, вона перенесла його до мене, хоч і намагалася вберегти мене» $[14$, с. 80], «...я переконаний, що вона шалено боялася за мене в ті часи, коли бути українцем стало державним злочином. Але я не пригадую ні одного випадку, коли б вона пробувала навернути мене до куди безпечнішої російськости» $[14$, с. 79].

Вищеозначені приклади малопомітні в Костюкових спогадах. Він був особистістю інтелектуально оснащеною, альтруїстом, про що свідчать спогади його сучасників. Зокрема, в листі (24.08.2002) до В. Мацька лікар Ярослав Туркало (1924-2009) писав: «Ви згадали імена деяких літераторів. Я, 
ISSN 2308-1902 Актуальні проблеми української літератури і фольклору. 2017. № 25.

розуміється, їх добре знаю особисто. Юрій Шевельов недавно відійшов у вічі 94 років. Григорій Олександрович Костюк за пару місяиів матиме 100 років. Я на його прохання колись їздв до Франиії, до Мужену, збирати деякі додаткові інформачї про В. Винниченка. Григорій Костюк надзвичайно гарна $i$ прачьовита людина, а головне великий патріот. Таких людей тепер в Украйні обмаль; Москва усіх передушила».

Доповнює літературний портрет Г. Костюка й Д. Нитченко, який, адресуючи В. Мацьку лист (17.06.1999), висловив таку думку: «Костюка я високо циную. Це чи не найкращий літературознавець $i$ знавещь підсовєтськой дійсності. Він знає всі партійні постанови й злочини партії. Вийшла на цюю тему окрема збірка розвідок. А найтрунтовніме він написав про літературне та політичне життя в своїх спогадах «Зустрічі і прощання», близько 600 сторінок. Довгі роки він очолював Спілку письменників «Слово» в Америці. Редактор низки книг та автор передмов» [9, с. 131].

Висновки. Автобіографічна нефікційна проза виявляється в наповненні твору фактами $з$ власного життя письменника. Саме такі критерії притаманні мемуарам Григорія Костюка, які можна назвати мемуарним автобіографічним романом у двох томах, позаяк вони обрамлені художніми засобами тропеїзації, ліризації, стилістичними фігурами. Мемуари Г. Костюка мають гібридний характер мемуарно-автобіографічної прози, увиразнюють жанрові модифікації художньо-документальної, публіцистичної прози nonfiction XX століття.

\section{ЛІТЕРАТУРА}

1. Арутюнова Н.Д. Дискурс. Лингвистический энииклопедический словарь / под ред. В.Н. Ярцевой. Москва: Советская энциклопедия, 1990. С. 136-137.

2. Галич О.А. Мемуари: масова чи елітарна література? // Актуальні проблеми слов'янської філології : міжвуз. зб. наук. ст. / відп. ред. В. А. Зарва, Ніжин : ТОВ «Видавництво «Аспект-Поліграф», 2007. С.191-196.

3. Горас Грей Лант. 3 приводу спогадів Шевельова. «Memo on Shevelov's memoires» : 3 англійської переклав Степан Захаркін за рукописом. URL : http:// krytyka.com/ua/articles/zpryvodu-spohadiv-shevelova (дата звернення 19.09.2017).

4. Костюк Григорій. Зустрічі і прощання : спогади . Едмонтон : Canadian Institute of Ukrainian Studies Press, 1987. Кн.1. 743 c.

5. Костюк Григорій. Зустрічі і прощання : спогади. Едмонтон; Торонто : Canadian Institute of Ukrainian Studies Press, 1998. Кн. 2. 609 c. 
6. Кошай Галина. Слово про Григорія Костюка // Творча спадщина Григорія Костюка в контексті сучасної наукової думки: Зб. наук. праць / за ред. В.П. Мацька. Київ; Хмельницький: Просвіта, 2002. С. 46-52.

7. Лежен Ф. В защиту автобиографии // Иностранная литература. 2000. № 4. С.108122.

8. Літературознавчий словник-довідник / за ред. Р.Г. Гром’яка, Ю.І. Коваліва, В.І. Терешка. Вид. друге, виправлене, доповнене. К. : Видавничий центр «Академія», 2007. 752 с.

9. Мацько В. Українська література: людина - світ - час. Хмельницький: ФОП Цюпак A.A., 2017. $228 \mathrm{c}$.

10. Мочульский К. В. Кризис воображения: Статьи; Эссе; Портреты / Сост., предисл. и комм. С. Р. Федякина. Томск: Водолей, 1999. 416 с.

11. Наєнко М. Що приховують мемуари Юрія Шевельова (Шереха)? Літературна Украӥна. 2012, 19 січня. С.10-11.

12. Рождественский Ю.В. Лекции по общему языкознанию: Учеб. пособие для вузов по филол. специальностям. 2-е изд. М.: Добросвет, 2000. 343 с.

13. Теория литературы: учеб. пособие для студ. филол. фак. высш. учеб. заведений: в 2 т. / под ред. Н.Д. Тамарченко. Т.1: Н.Д. Тамарченко, В.И. Тюпа, С.Н. Бройтман. Теория художественного дискурса. Теоретическая поэтика. М.: Издательский центр «Академия», 2010. 512 c.

14. Шевельов Ю. Я - мене - мені... (і довкруги): Спогади: у 2 кн. / Ю. Шевельов. Харків; Нью-Йорк: Видання часопису «Березіль»; Вид-во М. П. Коць, 2001. Кн. 1: В Європі. $432 \mathrm{c}$.

15. Bergonzi B. Late Victorian to Modernist (1880-1930) // The Oxford Illustrated History of English Literature. Oxford, N.Y., 1990. Pp. 379 - 430.

16. Herman D. Autobiography, allegory, and the construction of self // British Journal of Aesthetics 35. 4 (October 1995):351 (10 pages). URL : http: //cogweb.ucla.edu/Abstracts/Herman_95.html (дата звернення 25.09.2017).

\section{REFERENCES}

1. Arutyunova, N. (1990). Diskurs [Discourse] In N. Yartseva (Ed.), Lingvisticheskiy entsiklopedicheskiy slovar. [Linguistic encyclopedia] (pp. 136-137). Moscow: Sovetskaya entsiklopediya, 1990. [In Russian].

2. Halych, O. (2007). Memuary: masova chy elitarna literatura? [Memoires: mass or elitarian literature?] In V. Zarva (Ed.), Aktualni problemy slovianskoi filolohii [Topical issues of slavic philology] (pp. 191-196). Nizhyn : TOV “Vydavnytstvo 'Aspekt-Polihraf'”. [In Ukrainian].

3. Lunt, H. G. (2010) Z pryvodu spohadiv Shevelova [Memo on Shevelov's memoires] (S. Zakharkin, Trans.). Retrieved from http://krytyka.com/ua/articles/z-pryvodu-spohadiv-shevelova [In Ukrainian].

4. Kostiuk, H. (1987) Zustrichi i proshchannia: spohady [Greetings and farewells: memoires]. (Vol. 1). Edmonton: Canadian Institute of Ukrainian Studies Press. [In Ukrainian].

5. Kostiuk, H. (1998) Zustrichi i proshchannia: spohady [Greetings and farewells: memoires]. (Vol. 2). Edmonton: Canadian Institute of Ukrainian Studies Press. [In Ukrainian].

6. Koshai, H. (2002). Slovo pro Hryhoriia Kostiuka [A word on Hryhorii Kostiuk] In V. Matsko (Ed.), Tvorcha spadshchyna Hryhoriia Kostiuka v konteksti suchasnoi naukovoi dumky: Zb. nauk. prats [Creative heritage of Hryhorii Kostiuk in the context of contemporary humanities: Cpllection of scientific works] (pp. 46-52). Kyiv; Khmelnytskyi: Prosvita. [In Ukrainian].

7. Lejeune, P. (2000). V zashchitu avtobiografii [In protection of autobiography]. Inostrannaya literature, 4, 108-122. [In Russian]. 
ISSN 2308-1902 Актуальні проблеми української літератури і фольклору. 2017. № 25.

8. Hromiak, R. et al. (Eds.). (2007). Literaturoznavchyi slovnyk-dovidnyk [Literature studies vocabulary] ( $2^{\text {nd }}$ ed.). Kyiv: Vydavnychyi tsentr «Akademiia», 2007. [In Ukrainian].

9. Matsko, V. (2017). Ukrainska literatura: liudyna - svit - chas [Ukrainian literaturę: Human - World - Time]. Khmelnytskyi: FOP Tsiupak A.A. [In Ukrainian].

10. Mochulskiy, K. (1999). Krizis voobrazheniya: Stati; Esse; Portrety [Crisis of imagination: Articles; Essays; Portraits]. Tomsk: Vodoley. [In Russian].

11. Naienko, M. (2012). Shcho prykhovuiut memuary Yuriia Shevelova (Sherekha)? [What hides in Yurii Shevelov's memoires?] Literaturna Ukraina, (January, 19),10-11. [In Ukrainian].

12. Rozhdestvenskiy, Yu. (2000). Lektsii po obshchemu yazykoznaniyu: Ucheb. posobie dlya vuzov po filol. spetsialnostyam [Lectures on general linguistics: Teaching book for universities, philological branches]. ( $2^{\text {nd }}$ ed.). Moscow: Dobrosvet. [In Russian].

13. Tamarchenko, N. (Ed.). (2010). Teoriya literatury [Theory of literature] (Vol. 1). Moscow: Izdatelskiy tsentr «Akademiya». [In Russian].

14. Shevelov, Yu. (2001). Ya-mene-meni... (i dovkruhy): Spohady: u 2 kn. [Me - I was To me (and around): Memoires in two volumes]. (Vol. 2: In Europe). Kharkiv; New York: Vydannia chasopysu «Berezil»; Vydavnytstvo M. P. Kots.

15. Bergonzi, B. (1990). Late Victorian to Modernist (1880-1930) In The Oxford Illustrated History of English Literature. (pp. 379-430). Oxford, New York.

16. Herman, D. (n.d.). Autobiography, allegory, and the construction of self. Retrieved from: http: //cogweb.ucla.edu/Abstracts/Herman_95.html.

\title{
АННОТАЦИЯ \\ Людмила Джигун. Дискурс автобиографизма в воспоминаниях писателей украинской эмиграции
}

В статье доказано, что авторская субъективность организует произведение, порождает его художественную целостность и имеет различные формы. Направленность мышления Григория Костюка на тот или иной предмет, действие, явление формируется в мысль, которая зафиксирована на бумаге и является результатом интенциональной коммуникации в форме монолога, я-высказываний. Таким образом личное отношение к предмету изображения, воплощённое в языковой структуре произведения, является проявленим образа автора, его определенной мировоззренческой позицией.

Ключевые слова: поэтика, мемуаристика, автобиография, контекст, образ автора.

\begin{abstract}
Ludmila Dzhyhun. A discourse of autobiography in the memoirs of the writers of the Ukrainian diaspora

In this article it is proved that the author's subjectivity organizing work, creates its artistic integrity and has many forms. Orientation of Hryhorii Kostiuk thinking on a particular subject, action formed phenomenon in view, which is fixed on paper is the result intention communication in the form of a monologue, I-statements.

All the components of the artistic structure (facts, their location, character and method of narration) are important not only from a historical point of view, but also from the literary one, because skillfully written memoirs contribute to the study of the reflection of the aesthetic category of the writer (embodiment of the author's plan, his or her presentation of thoughts on paper), who selected the material, artistically worked it out and presented to the readers according to the actual formed world outlook, intentional idea, intentional essence of the consciousness, world
\end{abstract}


understanding. Thus personal attitude to the subject is embodied in the language structure of the work, is the image of the author.

The interaction of the autobiographical (individual) and general (reminiscence background) has led to the form of non-belletristic prose that contributed to the authors how to convey to readers the world-view paradigm, their own universe, understanding of the world, and to convey the spirit of the age, to join the process of the erasure of "white spots" in the history of Ukrainian literature.

Key words: poetics, memoir study, autobiography, context, the image of the author.

Стаття надійшла до редакційної колегії 01.12.2017 року 